\title{
Analysis of Students' E-Learning Capabilities on Academic Engagement at Umma University in Kenya
}

\author{
Bashir M. Maalim \\ Lecturer at School of Business and Technology \\ UMMA University, Garissa, Kenya.
}

\begin{abstract}
This study aimed at analyzing the influence of students' E-learning capabilities on academic engagement in UMMA University in Kenya. The objectives of the study were: to assess the influence of students' capabilities toward E-learning device on academic engagement in UMMA University in Kenya; to examine the influence of students' capabilities toward E-learning platform on academic engagement in UMMA University in Kenya and to evaluate the influence of student preparedness on academic engagement in UMMA University in Kenya. The study is pegged on two theories: The constructivist learning theory and the Engagement Theory. The study employed a cross-sectional descriptive research design. A total of 74 students were selected as respondents using a multi-staged sampling technique. A self-administered online questionnaire was used for data collection. The questionnaire was piloted for reliability and validity test prior to main data collection. Descriptive and inferential statistical analysis was done using Statistical Package for Social Science (SPSS) to run Structural Equation Model (SEM) in testing the developed null hypothesis and present data in form of tables, graphs and text form. Based on the study findings, there is a positive and significant influence the Student E-learning Capabilities (E-learning Devices, E-learning System and Student Preparedness) have on Academic Engagement. The study recommends provision and accessibility of affordable, dedicated institutional owned E-learning devices such as tablets to learners with in-stalled modules and applications to enhance the student Academic Engagement by reducing the over reliance of Smartphones. The study further recommends learning institutions to adopt a one-point entry platform that houses both E-learning and Student Management Information System (SMIS) to reduce too many logins which affects accessibility. Since majority of the learners ninety seven percent rely on Sim-Card based data bundles, the institution to sensitize them on subsidized negotiated bundles with major telecommunication companies in Kenya, this reduces the cost of the bundles and limits to the E-learning and some important internet access to academic sites. Enlighten learners on the use of cheap and alternative source of energy such as solar and power banks due to unreliable electricity in some locations which has been expressed as hindrance to E-learning accessibility. The study suggests similar research with larger sample and diverse learners from other campus, universities and learning centers. The study can research on the effect of technical support, Students' Socio-economic status, and
\end{abstract}

family background on academic engagement as possible part of the missing variance (twenty nine point five percent) that can fully explain the Academic Engagement.

Keywords:- Academic Engagement, E-learning, E-learning Capabilities, Learning Management System (LMS), Virtual Classroom.

\section{INTRODUCTION}

\section{A. Background to the Study}

The traditional mode of learning and teaching at different levels of learning institutions has been through physical classrooms where learners and teachers meet faceto-face in real-time. The emerging and advancement of technology for about two decades ago, the traditional method has moved to distance and virtual learning model known as E-learning (Ansong, Lovia Boateng, \& Boateng, 2017). E-learning is defined as teaching and learning instructions delivered through electronic devices such as mobile devices, personal computers among others with an aim of supporting learning activities (Clark \& Mayer, 2011)

E-learning model is classified into three categories: Synchronous - Real-time interaction between learners and instructors; Asynchronous - Non real-time interaction between learners and instructors at owns time and pace; and blended model - a mix of the Synchronous and Asynchronous with a face-to-face option for an interaction via physical and video conferencing platforms (Algahtani, 2011)

E-learning as a study mode for many of the university programs rests on three main inter and intra-connections; faculty management, learners and lecturers (Persico, Manca, \& Pozzi, 2014). Each of the three main stakeholders play critical role that influences the success of e-learning activities in an institution.

E-learning Mode has undergone three major phases since its inception: First phase between 1994 and 1999, there has been utilization of technology and internet in transforming learning materials from hard to soft copies and online versions. Second phase between 2000 and 2003 an increase and expansion of internet band-width enabling media streaming and virtual classrooms with student services ranging between accessing learning materials, inter and intra communication with peer learners and lecturers. Third phase from 2004 to date incorporating social aspects, 
learning based on project and reflective approach through simulations and networking (Popovici \& Mironov, 2015).

Globally, E-learning is widely used in developed countries more than the developing countries (Tagoe, 2012). However, the past two decades there is notable intensive stride made by Universities in Africa toward E-learning incorporation in their programs. In the US, students are fully participating in courses through E-learning platforms (Allen \& Seamen, 2008). In European countries, the use of Elearning mode of teaching is widely spread with blended model $(91 \%)$, Pure Online provision $(82 \%)$, offering online degrees $(39 \%)$ to attract more learners, reduce the cost of running physical structures and improve quality (Gaebel, Kupriyanova, Morais \& Colucci, 2014).

In Africa, E-learning has been growing at a pace in pre COVID-19 and seems to be the only mode of learning to continue for a while due to the increasing infection rate and lack of cure, vaccine and treatment for the COVID-19. Many countries including Uganda and Zimbabwe have adopted the E-learning mode (Kasse \& Balunywa, 2013).

In Kenya, establishment and implementation of Elearning mode of teaching and learning though in a blended form (a mix of face-to-face and distance/virtual mode) among public and private universities started more than a decade ago, for instance, University of Nairobi (UoN) in 2004 using Wedusoft, Kenyatta University (KU) in 2005 using Moodle, Jomo Kenyatta University of Agriculture and Technology (JKUAT) in 2006 using Moodle and Moi University (MU) in 2007 using MUSOMI similar to Wedusoft (Tarus, \& Gichoya, 2015). A total of 8 stateowned and 5 privately-owned universities run academic programs on E-learning mode (Nyerere, 2016).

The fast spreading of the Corona Virus Disease (COVID-19) and its effect has called for strict measures such as social-distancing, frequent hand-washing with running water and soap, and a lockdown to reduce the infection rate. The preventive measures led to a paradigm shift in the access and supply of various services such as teaching \& learning in schools and higher learning institution. An instant closure of schools and post-secondary institutions called for an alternative mode of teaching across the globe (Bayham \& Fenichel, 2020).

\section{B. The Research Problem}

With the global outbreak of COVID-19 pandemic, similar to many countries in the world, the Kenyan government ordered closure of all learning institutions and recommended use of distance learning mode of teaching across all the universities to reduce the rate of infection spread (Ngwacho, 2020). Since the establishments of distance and e-learning mode various challenges have dominated academic literature on E-learning.

At the third graduation ceremony in UMMA University in Kenya held in June 2020, the Vice Chancellor reported that about $30 \%$ of student population had not interacted with the university E-learning platform. The arising research question for this study: Is student's Elearning Capabilities a missing factor with a potential to influence academic engagement?

The inability of students to interact with the university e-learning platform has a dire consequence by denying the right to education coupled with mental health issues as their peers pursue their education. Thus, this justified the need for academic researches to the identified problem expected to enable the policy and decision makers within and outside the universities' arena to utilize the findings and make an informed decision.

Various studies have researched on the effect of Elearning on academic performance in Kenya (Owino, 2013) in India (Suresh, Vishnu Priya, \& Gayathri, 2018), student engagement through digital readiness in China (Kim, Hong $\&$ Song, 2019). None of the reviewed literature has researched on the influence of Students' E-learning Capabilities on Academic Engagement; hence this study filled the knowledge and research gap on the topic.

\section{Objectives of the Study}

The purpose of the study was to analyze the influence of Students' E-learning Capabilities on Academic Engagement in UMMA University in Kenya through the following objectives;

To assess the influence of students' capabilities toward E-learning device on academic engagement in UMMA University in Kenya.

$>$ To examine the influence of students' capabilities toward E-learning platform on academic engagement in UMMA University in Kenya.

$>$ To evaluate the influence of student preparedness on academic engagement in UMMA University in Kenya.

D. Hypothesis of the Study

Ho1 Students' Capabilities toward E-learning device does not significantly influence academic Engagement in UMMA University in Kenya.

$\mathbf{H}_{02}$ Students' Capabilities toward E-learning system does not significantly influence academic Engagement in UMMA University in Kenya.

$\mathbf{H}_{03}$ Students' Preparedness does not significantly influence academic Engagement in UMMA University in Kenya.

\section{LITERATURE REVIEW}

\section{A. Empirical Review}

Link \& Marz (2006) in their study on Computer skills, access challenges and E-learning attitudes among first year medical students in Vienna found that majority had prior computer skills while a few lack sufficient skills and this had positive and negative impact to their E-learning respectively. Their study concluded the need for sufficient exposure to computer skills for successful E-learning. This study looked further at students' access to electronic device, skills to operate and troubleshoot to determine its impact on academic engagement. 
Tagoe (2012) in a study to determine student perception on E-learning in Ghana University found that students with good command of computer operation actively participated in the E-learning and preferred more of blended model of E-learning. This study looked further into student capabilities toward E-learning systems; accessibility, navigation, and troubleshooting to examine its effect on academic engagement.

Parkes, Stein \& Reading (2014) in their study to determine how students are prepared towards E-learning in Australia found that despite their reasonable preparedness students were not well prepared. This study looked further into student preparedness in terms of access to internet and electricity services, and time management to assess its influence on academic engagement.

Lazareva (2018) conducted a study on student engagement in E-learning in Uganda using qualitative method, the study found four issues affecting Students' engagement with E-learning courses; course environment, Peer-interaction, online-group dynamics and informal online-groups formed by learners. This study looked further into three categories; Class attendance, class activities (exams, assignments, and course materials) and class interaction among their peers and lecturers and in a mixed research method whose results can be generalized.

\section{B. Theoretical Framework}

The study is pegged on two theories: The constructivist learning theory - a widely applied theory which forms basic framework for E-learning. The theory highlights that students are given opportunity to interpret and decode information through their own individual experiences and perception. This Theory is suitable to this study through the independent variables; Students' E-learning capabilities towards devices and systems as well as student preparedness for the E-learning.

The Engagement Theory for the student academic engagement as they postulate the active engagement or involvement in the learning procedure based on interactivities among themselves or with lecturers, academic activities such as attendance, quizzes, and exercises for students to learn better. This theory is suitable to this study through the dependent variable; Academic Engagement on Class attendance, Class activities and Class interaction.

\section{Conceptual Framework}

The conceptual framework for this study depicts the independent variables; E-learning Devices, E-learning System and Student Preparedness with respective four elements each to measure the influence of the variables, the dependent variable; Academic engagement with three elements to measure the influence of the variable as shown in figure 1 below.

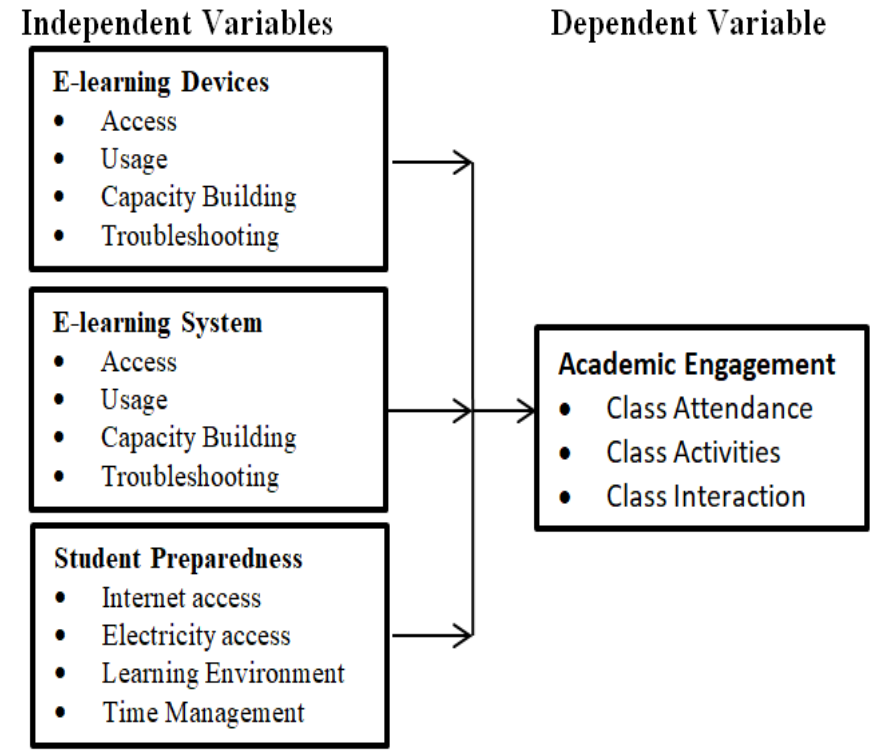

Fig 1:- Conceptual Framework Source: Researcher (2020)

\section{RESEARCH METHODS}

\section{A. Research Design}

This study adopted cross-sectional descriptive research design to examine the objectives of the study and testing the developed null hypotheses. Research design acts as a blueprint of a study encompassing a complete set layout from questionnaire development, to data collection and data analysis and its interpretation (Kothari \& Gaurav, 2014).

\section{B. Sampling Technique And Sample Size}

A multi-staged sampling technique has been used to select respondents for this study; Purposive method in selecting the Garissa Learning Centre as study locality which has quite number of students, Stratified method basing on Academic level (Certificate, Diploma and Degree) and random method to select respondent till the assigned quota per academic level has been reached.

A total sample size of 74 students were selected as respondents for this study using Tabachnick \& Fidell (2013) suggested formulae to calculate sample size for the study: $\mathrm{n} \geq 50+8 \mathrm{M}$

Where: $\mathrm{n}$ is sample size for respondents to the study and $M$ represents number of variables (independent Variables) used in the study which is 3 variables for this study: Thus $\mathrm{n} \geq 50+8 * 3$; $\mathrm{n} \geq 50+24$; $\mathrm{n} \geq 74$

Proportionate to population Size (PPS) of the student population at the learning center. 


\begin{tabular}{|c|c|c|c|}
\hline Cluster & Population & Percentage & Sample Size \\
\hline Certificate & 144 & $23 \%$ & 17 \\
\hline Diploma & 193 & $31 \%$ & 23 \\
\hline Degree & 294 & $47 \%$ & 34 \\
\hline Total & 631 & $100 \%$ & 74 \\
\hline
\end{tabular}

Table 1:- Sample Size

Source: Researcher (2020)

\section{Data Collection Instrument And Analysis}

A questionnaire was used to collect data in form of qualitative and quantitative, a five-point Likert Type Scale has been used; (Strong Disagree, Disagree, Neutral, Agree and Strongly Agree). The questionnaire was piloted prior to actual data collection to ascertain reliability and validity of the tool. Data collection was done through online designed questionnaire/forms using Kobo collect and distributed among students.

For quantitative data, descriptive and inferential statistical analysis through Statistical Package for Social Science (SPSS) has been used to run Structural Equation Model (SEM), to test the developed hypothesis and generate tables. For qualitative data, content analysis has been used to analyze.

Structural Equation Model (SEM) for this study:

$$
Y=\beta_{0}+\beta_{1} X_{1}+\beta_{2} X_{2}+\beta_{3} X_{3}+\varepsilon
$$

\section{Where:}

$\mathrm{Y}=$ Academic Engagement,

$\beta_{\mathrm{i}} \mathrm{i}=0,1,2$ and 3 are Constant and Regression Coefficient,

$X_{i} i=1,2,3, \ldots$ are independent variables (E-learning Devices, E-learning System and Student Preparedness respectively) while $\varepsilon$ is an error term explaining the unknown variation of the model.

\section{RESULTS AND DISCUSSIONS}

\section{A. Demographic features of the respondents}

\begin{tabular}{|c|c|c|}
\hline Gender & Number & Percentage \\
\hline Male & 29 & $39 \%$ \\
\hline Female & 45 & $61 \%$ \\
\hline Total & 74 & $100 \%$ \\
\hline
\end{tabular}

Table 2:- Gender of the respondent

Source: SPSS Output on Field Data (2020)

Table 2 shows the breakdown of the respondent based on gender; male $39 \%(n=29)$, Female $61 \%(n=45)$. A fair distribution of the gender participation and represents the proportion in the student population.

\begin{tabular}{|c|c|c|}
\hline Age bracket & Number & Percentage \\
\hline $17-20$ & 21 & $28 \%$ \\
\hline $21-25$ & 30 & $41 \%$ \\
\hline $26-30$ & 13 & $18 \%$ \\
\hline More than 31 & 10 & $14 \%$ \\
\hline Total & $\mathbf{7 4}$ & $\mathbf{1 0 0 \%}$ \\
\hline
\end{tabular}

Table 3:- Age distribution of the respondents

Source: SPSS Output on Field Data (2020)
Table 3 shows the age distribution among the respondent, more than $50 \%$ are a category alluded as "digital generation" (Lazareva, 2018).

\section{B. Validity and reliability Tests}

\begin{tabular}{|c|c|c|}
\hline Variable & Factor Loading & Remarks \\
\hline E-learning Devices & .821 & Valid \\
\hline E-learning System & .878 & Valid \\
\hline Students' Preparedness & .891 & Valid \\
\hline Academic Engagement & .873 & Valid \\
\hline
\end{tabular}

Table 4:- Validity Test using Factor Analysis

Source: SPSS Output on Field Data (2020)

Table 4 above shows the validity tests results for the questionnaire used for data collection. Tabachnick \& Fidell (2013) consider any factor loading above 0.7 to be excellent; the table shows the least with 0.821 , hence affirms the data collection tool used to have been valid.

Similarly, the validity of the questionnaire prior to actual fieldwork has been cross checked with peers to ascertain whether the set questions will attract data that can be used to test the developed hypothesis of the study.

\begin{tabular}{|c|c|c|}
\hline Variable & Cronbach Alpha & Remarks \\
\hline E-learning Devices & .831 & Reliable \\
\hline E-learning System & .859 & Reliable \\
\hline Students' Preparedness & .901 & Reliable \\
\hline Academic Engagement & .862 & Reliable \\
\hline
\end{tabular}

Table 5:- Reliability Test

Source: SPSS Output on Field Data (2020)

Table 5 shows the reliability tests results which indicates Cronbach alpha above 0.7 to be reliable. The results show the least value as 0.831 and thus an indication that the questionnaire has been reliable.

\section{Descriptive Statistics}

\begin{tabular}{|c|c|c|c|c|}
\hline \multicolumn{5}{|c|}{ Descriptive Statistics } \\
\hline & $\mathrm{N}$ & Mean & $\begin{array}{c}\text { Std. } \\
\text { Deviation }\end{array}$ & Variance \\
\hline Academic Engagement & 74 & 3.6351 & 5.20105 & 27.051 \\
\hline E-learning Device & 74 & 3.6047 & 4.24266 & 18.000 \\
\hline E-learning system & 74 & 3.7919 & 3.21997 & 10.368 \\
\hline Student Preparedness & 74 & 4.1784 & 6.58104 & 43.310 \\
\hline Valid N (listwise) & 74 & & & \\
\hline
\end{tabular}

Table 6:- Descriptive Statistics

Source: SPSS Output on Field Data (2020)

Table 6 shows values of mean and standard deviation for the the study variables; Academic engagement, Elearning Devices, E-learning System and Student Preparedness with their means ranging between 3.6351 and 4.1784 whose lowest value shown as above average (the middle value in the Five-Point Likert Type Scale = 3) indicating existence of the study variables in the academic institution. The student Preparedness leading with a mean of 4.178 . 
ISSN No:-2456-2165

\section{Hypothesis Testing}

The study developed null hypotheses and a Pearson Correlation has been run to test them whose decision rule is more or less than zero (Positive/negative) relation between the independent and dependent variables to reject null hypothesis with significant level of $5 \%(\alpha=0.05)$.

\begin{tabular}{|c|c|c|c|}
\hline \multirow{4}{*}{ Correlations $^{\mathbf{b}}$} \\
\cline { 2 - 4 } & \multicolumn{3}{|c|}{ Independent Variable } \\
\hline Dependent Variable & $\begin{array}{c}\text { E-learning } \\
\text { Device }\end{array}$ & $\begin{array}{c}\text { E-Learning } \\
\text { System }\end{array}$ & $\begin{array}{c}\text { Student } \\
\text { Preparednes } \\
\text { Depen }\end{array}$ \\
\hline $\begin{array}{c}\text { Academic Engagement } \\
\text { Pearson Correlation } \\
\text { Sig. (2-tailed) }\end{array}$ & $.517^{*}$ & $.581^{*}$ & $.770^{*}$ \\
\cline { 2 - 4 } & .000 & .000 & .000 \\
\hline
\end{tabular}

*. Correlation is significant at the 0.05 level (2-tailed).

b. Listwise $\mathrm{N}=74$

Table 7:- Pearson Correlation Coefficients

Table 7 shows results of Pearson Correlation Coefficient run for testing the developed study hypothesis. The result shows positive and significant relation between the independent and dependent variables. E-learning Devices (ED) has a moderate positive $(0.517)$ relation with Academic Engagement (AE) at 5\% significant $(0.001<0.05)$, E-learning Systems (ES) has a moderate positive (0.581) relation with Academic Engagement (AE) at $5 \%$ significant $(001<0.05)$ and Students Preparedness (SP) has a strong positive $(0.770)$ relation with Academic Engagement $(\mathrm{AE})$ at $5 \%$ significant $(0.01<0.05)$.

Based on the above results, the three null hypotheses are rejected, and hence adapt the alternative hypothesis supporting the purpose of the study: Students' E-learning Capabilities influence Academic Engagement at UMMA University in Kenya.

\begin{tabular}{|c|c|c|}
\hline Type of Device & Access & Ownership \\
\hline Smartphone & $95 \%(\mathrm{n}=70)$ & $100 \%(\mathrm{n}=70)$ \\
\hline Tablet & $3 \%(\mathrm{n}=2)$ & $50 \%(\mathrm{n}=1)$ \\
\hline Laptop & $5 \%(\mathrm{n}=4)$ & $40 \%(\mathrm{n}=2)$ \\
\hline Desktop & $4 \%(\mathrm{n}=3)$ & $33 \%(\mathrm{n}=1)$ \\
\hline
\end{tabular}

Table 8:- Device Access and Ownership Source: Field Data (2020)

Table 8 shows device access and ownership, the result show that $95 \%, 12 \%, 9 \%$ and $8 \%$ of the respondents have an access to a Smartphone, Laptop, Desktop and Tablet that can be used for E-learning while 100\%, 40\%, 33\% and 50\% own them respectively.

This indicates majority (95\%) of the learners use smartphones as device for the E-learning activities followed by the computers (Tablet, Laptop and Desktop) at $12 \%$ (9 learners). The smartphones are not only dedicated for Elearning but used for other purposes such as calls, social media and Short Message Service (SMS) which causes interruption during the usage for E-learning activities.

\begin{tabular}{|c|c|}
\hline Internet Source & Percentage \\
\hline WiFi installed at home & $7 \%(\mathrm{n}=5)$ \\
\hline WiFi installed at Office & $9 \%(\mathrm{n}=7)$ \\
\hline Public WiFi (Hotels, Café' ... etc) & $41 \%(\mathrm{n}=30)$ \\
\hline Sim Card based (Data Bundles) & $97 \%(\mathrm{n}=72)$ \\
\hline Other (neighbours, friends... etc) & $20 \%(\mathrm{n}=15)$ \\
\hline
\end{tabular}

Table 9:- Source of Internet used for E-learning

Table 9 shows the source of internet used for Elearning activities, majority $(97 \%)$ of the learners rely on data bundles purchased from telecommunication companies, $41 \%$ from Public WiFi, $20 \%$ from other sources such as friends' or neighbours' bundles/WiFi while $9 \%$ and $7 \%$ from $\mathrm{WiFi}$ installed at home or office respectively.

\section{E. Structural Equation Model (SEM)}

A Structural Equation Model (SEM) has been developed to determine the level of impact and the extent the independent variables have and contribute toward the dependent variable.

\begin{tabular}{|c|c|c|c|c|}
\hline \multicolumn{5}{|c|}{ Model Summary } \\
\hline Model & $\mathrm{R}$ & R Square & $\begin{array}{c}\text { Adjusted R } \\
\text { Square }\end{array}$ & $\begin{array}{c}\text { Std. Error of the } \\
\text { Estimate }\end{array}$ \\
\hline 1 & $.840^{\mathrm{a}}$ & .705 & .693 & 2.88265 \\
\hline
\end{tabular}

a. Predictors: (Constant), Student Preparedness, E-learning system, E-learning Device

Table 10:- Model Summary

Table 10 shows a model summary of the Structural Equation Model for the study with $70.5 \%$ variance of Academic Engagement (AE) being explained by E-learning Device (ED), E-learning System (ES) and student Preparedness (SP) while $29.5 \%$ is explained by other factors.

\begin{tabular}{|c|c|c|c|c|c|}
\hline \multicolumn{7}{|c|}{ ANOVA $^{\text {a }}$} \\
\hline Model & $\begin{array}{c}\text { Sum of } \\
\text { Squares }\end{array}$ & Df & $\begin{array}{c}\text { Mean } \\
\text { Square }\end{array}$ & F & Sig. \\
\hline Regression & 1393.038 & 3 & 464.346 & 55.880 & $.000^{\mathrm{b}}$ \\
\hline Residual & 581.678 & 70 & 8.310 & & \\
\hline Total & 1974.716 & 73 & & & \\
\hline \multicolumn{7}{|c|}{ a. Dependent Variable: Academic Engagement } \\
\hline b. Predictors: (Constant), Student Preparedness, E-learning \\
system, E-learning Device \\
\hline
\end{tabular}

Table 11:- ANOVA Table

Table 11 shows Analysis of Variance (ANOVA) which indicates the significance outcome of the model and the P-value is .001 and less than .05 significance level $(5 \%)$. This indicates the study Structural Equation Model (SEM) to be statistically significant. 


\begin{tabular}{|c|c|c|c|c|c|}
\hline \multicolumn{6}{|c|}{ Coefficients $^{\mathrm{a}}$} \\
\hline \multirow[b]{2}{*}{ Model } & \multicolumn{2}{|c|}{$\begin{array}{l}\text { Unstandardized } \\
\text { Coefficients }\end{array}$} & \multirow{2}{*}{\begin{tabular}{|c|}
$\begin{array}{c}\text { Standardi } \\
\text { zed } \\
\text { Coefficie } \\
\text { nts }\end{array}$ \\
Beta \\
\end{tabular}} & \multirow[b]{2}{*}{$\mathrm{t}$} & \multirow[b]{2}{*}{ Sig. } \\
\hline & $\mathrm{B}$ & Std. Error & & & \\
\hline \multirow{4}{*}{$\begin{array}{c}\text { (Constant) } \\
\text { E-learning Device } \\
\text { E-learning system } \\
\text { Student } \\
\text { Preparedness }\end{array}$} & .920 & .285 & & .681 & .048 \\
\hline & .277 & .130 & .226 & 2.137 & .036 \\
\hline & .756 & .153 & .468 & 4.926 & .000 \\
\hline & .565 & .062 & .715 & 9.112 & .000 \\
\hline
\end{tabular}
a. Dependent Variable: Academic Engagement

Table 12 shows the coefficients of the variables in the model indicating E-learning Device (ED), E-learning System (ES) and Student Preparedness (SP) having a positive significant influence on Academic Engagement (AE) with $\mathrm{t}=2.137$, $\mathrm{t}=4.926, \mathrm{t}=9.112$ and significant values $.036, .001$ and .001 respectively less than the $5 \%$ significance level decision rule.

\section{Table 12:- Coefficients Table}

Inserting the values from the coefficients table into the Structural Equation Model (SEM):

$\mathrm{Y}=.920+.277 \mathrm{X}_{1}+.756 \mathrm{X}_{2}+.565 \mathrm{X}_{3}$

Academic Engagement $=.920+.277($ E-learning Device + .756 (E-learning System) + .565 (Student Preparedness).

\section{CONCLUSION, RECOMMENDATION AND SUGGESTIONS FOR FURTHER RESEARCH}

The study aimed at analyzing the influence of Student's E-learning Capabilities (E-learning Device, Elearning System and Student Preparedness) on Academic Engagement at UMMA University in Kenya. Based on the study findings, there is a positive and significant influence the Student E-learning Capabilities have on Academic Engagement.

The study recommends provision and accessibility of affordable, dedicated institutional owned E-learning devices such as tablets to learners with installed modules and applications to enhance the student Academic Engagement by reducing the over reliance of Smartphones.

The study further recommends learning institutions to adopt a one-point entry platform that houses both Elearning and Student Management Information System (SMIS) to reduce too many logins which affects accessibility.

Since majority of the learners $(97 \%)$ rely on SimCard based data bundles, the institution to sensitize them on subsidized negotiated bundles with major telecommunication companies in Kenya, this reduces the cost of the bundles and limits to the E-learning and some important internet access to academic sites.
Enlighten learners on the use of cheap and alternative source of energy such as solar and power banks due to unreliable electricity in some locations which has been expressed as hinderance to E-learning accessibility.

The study suggests similar research with larger sample and diverse learners from the other campus and learning centres. The study can research on the effect of technical support, Students' Soci-economic status, and family background on academic engagement as possible part of the missing variance $(29.5 \%)$ that can explain the Academic Engagement.

\section{REFERENCES}

[1]. Algahtani, A. (2011): Evaluating the Effectiveness of the E-learning Experience in Some Universities in Saudi Arabia from Male Students' Perceptions, Durham University.

[2]. Ansong, E., Lovia Boateng, S., \& Boateng, R. (2017). Determinants of E-Learning Adoption in Universities: Evidence From a Developing Country. Journal of Educational Technology Systems, 46(1), 30-60.

[3]. Bayham J, Fenichel EP. Impact of school closures for COVID-19 on the US health-care workforce and net mortality: a modelling study. Lancet Public Heal. 2020;5:e271-8.

[4]. Clark, R., Mayer, R. (2011) E-learning and the science of instruction: Proven guidelines for consumers and designers of multimedia learning, 3rd ed. San Francisco, CA: Pfeiffer.

[5]. Gaebel, M., Kupriyanova, V., Morais, R., \& Colucci, E. (2014). E-learning in European higher education institutions. Brussels: European University Association.

[6]. Kasse, J. P., \& Balunywa, W. (2013, February). An assessment of e-learning utilization by a section of Ugandan universities: challenges, success factors and way forward. In International conference on ICT for Africa (Vol. 15).

[7]. Kim, H. J., Hong, A. J., \& Song, H. D. (2019). The roles of academic engagement and digital readiness in students' achievements in university e-learning environments. International Journal of Educational Technology in Higher Education, 16(1), 21.

[8]. Kothari, C., \& Garg, G. (2014). Research Methodology: Methods and Strategy. New age international.

[9]. Lazareva, A. (2018). Factors Affecting Student Engagement in Online Collaborative Learning Courses. 10.1007/978-3-319-73204-6_39.

[10]. Link, T.M., Marz, R. (2006). Computer literacy and attitudes towards e-learning among first year medical students. BMC Med Educ 6, 34. https://doi.org/10.1186/1472-6920-6-34

[11]. Ngwacho A. G, (2020): COVID-19Pandemic Impact on Kenyan Education Sector: Learner Challenges and Mitigations. Journal of Research and Implication in Education 
[12]. Nyerere, J. (2016). Open and distance learning in Kenya: A baseline survey report commissioned by the Commonwealth of Learning.

[13]. Owino, O. (2013). The impact of e-learning on academic performance: A case study of group learning sets. Unpublished Masters Project. University of Nairobi.

[14]. Parkes, M., Stein, S. \& Reading, C. (2014). Student preparedness for university e-learning environments. The Internet and Higher Education.

[15]. Persico, D., Manca, S., Pozzi, F. (2014) Adapting the technology acceptance model to evaluate the innovative potential of e-learning systems. Computers in Human Behavior 30: 614-622.

[16]. Popovici, A. \& Mironov, C. (2015). Students' Perception on Using eLearning Technologies. Procedia - Social and Behavioral Sciences. 180. 1514-1519.

[17]. Suresh, M., Vishnu Priya, V., \& Gayathri, R. (2018). Effect of e-learning on academic performance of undergraduate students. Drug Invention Today, 10(9).

[18]. Tabachnick, B. G., \& Fidell, L. S. (2013). Using multivariate statistics: International edition. Pearson.

[19]. Tagoe, M. (2012). Students' perceptions on incorporating e-learning into teaching and learning at the University of Ghana. International Journal of Education and Development using Information and Communication Technology (IJEDICT), 2012, Vol. 8, Issue 1, pp. 91-103.

[20]. Tarus, J.K., \& Gichoya, D. (2015). E-Learning in Kenyan Universities: Preconditions for Successful Implementation. EJISDC: The Electronic Journal on Information Systems in Developing Countries, 66, 6. 